\title{
PENGEMBANGAN LAGU EDUKASI MATEMATIKA DALAM PEMBELAJARAN MATEMATIKA DENGAN MENGGUNAKAN METODE EDUTAINMENT DI KELAS V SDN KELEYAN 1 SOCAH
}

\author{
Putri Diah Kusuma Wardani ${ }^{1)}$, Mohammad Edy Nurtamam ${ }^{2)}$, Fachrur Rozie ${ }^{3)}$ \\ 1,2,3) Program Studi PGSD FIP Universitas Trunojoyo Madura \\ E-mail: putridiahkw@gmail.com
}

\begin{abstract}
ABSTRAK. Pembelajaran matematika yang dilaksanakan di Kelas V SDN Keleyan 1 Socah masih menggunakan metode ceramah dengan minimnya penggunaan media pembelajaran. Penelitian ini bertujuan untuk mengembangkan lagu edukasi matematika dengan metode edutainment yang layak digunakan dari segi kevalidan lagu, kemenarikan, keefektifan, dan mudah digunakaan dalam pelaksanaannya di SDN Keleyan 1 Socah. Penelitian ini menggunakan metode penelitian pengembangan dengan model pengembangan Borg and Gall yang telah di adaptasi oleh Sugiyono. Hasil peneltian ini menunjukkan bahwa hasil ujicoba kevalidan media dari validator yaitu ahli materi pembelajaran 98,67\%, ahli media pembelajaran 94,67\%, dan ahli desain pembelajaran 90,67\% dengan kategori sangat valid, hasil uji kemenarikan berdasarkan respon siswa pada ujicoba produk $96,67 \%$ dan ujicoba pemakaian $97,50 \%$ dengan kategori sangat menarik. Hasil uji keefektifan media berdasarkan hasil observasi aktifitas guru dan siswa pada ujicoba produk dan pemakaian, pada ujicoba produk hasil observasi aktivitas guru $100 \%$ dan observasi aktivitas siswa 96,34\%. Pada ujicoba pemakaian, hasil observasi aktivitas guru $100 \%$ dan observasi aktifitas siswa 96,25\% dengan hasil ketuntasan klasikal siswa 96,88\% dengan kategori sangat efektif. Hasil uji kepraktisan berdasarkan respon guru sebesar $100 \%$ dengan kategori sangat praktis. Kesimpulan penelitian ini adalah media pembelajaran Lagu Edukasi Matematika sangat layak digunakan untuk materi bangun ruang siswa kelas V di SDN Keleyan 1 Socah.
\end{abstract}

Kata Kunci: Media Pembelajaran, Lagu Edukasi Matematika, Bangun Ruang, Pembelajaran Matematika

\section{Pendahuluan}

Proses belajar mengajar atau proses

pembelajaran merupakan suatu kegiatan

melaksanakan kurikulum suatu lembaga

pendidikan agar dapat mempengaruhi para

siswa mencapai tujuan pendidikan yang telah

ditetapkan. Tujuan pendidikan pada dasarnya mengantarkan para siswa menuju pada perubahan-perubahan tingkah laku baik intelektual, moral maupun sosial agar dapat hidup mandiri sebagai individu dan makhluk sosial. Para guru dalam pembelajaran terutama mata pelajaran Matematika pada umumnya melakukan proses belajar dikelas dengan pemberian materi-materi secara abstrak yang tidak diperbanyak dengan interaksi antara guru dan siswa. Untuk menunjang pembelajaran di kelas diperlukan sarana dan prasarana pendukung berupa alat bantu atau media.

Berdasarkan studi awal yang diperoleh melalui hasil observasi, wawancara dan hasil angket analisis kebutuhan siswa menyatakan bahwa sebanyak $61,11 \%$ siswa menyukai pelajaran Matematika. 66,67 \% siswa berpendapat bahwa pembelajaran matematika 
di kelas itu sulit dan membosankan. Menurut siswa pembelajaran didalam kelas tidak pernah menggunakan media pembelajaran dan guru tidak pernah mengajak siswa bermain sambil belajar saat di kelas. Sebanyak 72,22 \% siswa suka bernyanyi dan $100 \%$ siswa di dalam kelas setuju apabila dalam pembelajaran matematika di kelas mengguakan lagu agar pembelajaran menjadi efektif dan menyenangkan.

Hasil studi awal tersebut memberikan gambaran kepada peneliti untuk mengembangkan media lagu pembelajaran, yakni lagu yang liriknya merupakan materi pelajaran matematika. Tujuan dilaksanakannya penelitian dan pengembangan ini adalah untuk mengembangkan lagu edukasi matematika dalam pembelajaran matematika dengan metode edutainment yang layak digunakan dari segi kevalidan, kemenarikan, keefektifan, dan kepraktisan lagu kelas V SD dengan metode edutainment materi bangun ruang.

Media pembelajaran merupakan alat bantu berupa fisik maupun nonfisik yang sengaja digunakan sebagai perantara antara guru dan siswa dalam memahami materi pelajaran agar lebih efektif dan efisien. Hal tersebut bertujuan agar materi pembelajaran lebih cepat diterima siswa dengan utuh serta menarik minat siswa untuk belajar lebih lanjut (Musfiqon, 2012:28)

Media lagu edukasi dapat dijadikan sebagai alternatif dalam kegiatan belajar mengajar agar lebih menyenangkan karena apabila siswa dalam kondisi senang ketika belajar maka materi yang disampaikan oleh guru akan dimengerti dengan baik. Lagu atau nyanyian dapat digunakan sebagai media penyampaian pesan yang menyenangkan bagi anak. Lagu tidak dapat dipisahkan dari kegiatan pembelajaran pada anak (Rasyid, 2010:147).

Anak-anak bermain dengan lagu, bahkan mereka belajar dengan lagu Sehingga adanya lagu edukasi dapat diterapkan dalam sebuah metode pembelajaran Edutainment yang membuat siswa lebih mudah mengingat rumus dan materi yang sedang dipelajari melalui lagu serta proses belajar yang menghibur. Metode edutainment adalah suatu proses pembelajaran yang didesain sedemikian rupa, sehingga muatan pendidikan dan hiburan bisa dikombinasikan secara harmonis untuk menciptakan pembelajaran yang menyenangkan (Hamid, 2014:17) .

\section{Metode Penelitian}

Metode yang digunakan dalam penelitian ini adalah metode penelitian dan pengembangan (Research and Development) atau R\&D dengan menggunakan model pengembangan Borg and Gall yang diadaptasi oleh Sugiyono (2014:297). Model pengembangan ini memiliki sepuluh tahap kegiatan yang meliputi: (1) identifikasi masalah, (2) pengumpulan informasi, (3) desain produk, (4) validasi desain, (5) perbaikan desain, (6) uji coba produk, (7) revisi 
produk, (8) uji coba pemakaian, (9) revisi produk tahap akhir, (10) peoduksi masal.

Pengembang memberikan batasan pada tahap pengembangan yang akan dilakukan yaitu pengembangan media pembelajaran dilakukan sampai pada tahap revisi produk akhir. Pengembang tidak melakukan tahap produksi massal, karena keterbatasan waktu, biaya, dan tenaga serta hanya diuji cobakan pada satu tempat yaitu SDN Keleyan 1 Socah. Subyek ujicoba pada penelitian ini adalah validator ahli, guru, dan siswa.

Pada tahap desain produk terdapat enam langkah pembuatan produk, yaitu pembuatan listrik lagu, aransemen lagu, rekaman, menggabungkan aransemen lagu dengan rekaman, produksi lagu tahap awal, dan membuat buku panduan lagu. Langkah selanjutnya adalah menguji valid tidaknya produk.

Tahap uji validasi dilakukan dengan memvalidasi instrumen dan produk lagu edukasi kepada para ahli. Validasi oleh ahli digunakan untuk mengetahui kevalidan produk awal dengan memberikan masukan terhadap lagu edukasi untuk mengetahui kekurangankekurangan yang terdapat didalamnya. Validasi desain dilakukan oleh tiga ahli yaitu ahli materi, ahli media, dan ahli desain pembelajaran, setelah melaksanakan tahap validasi ahli dilakukakan perbaikan desain sesuai hasil angket validasi, kritik, dan saran yang diberikan oleh validator.
Desain uji coba merupakan rangkaian kegiatan uji coba yang akan dilakukan dalam proses pengembangan media pembelajaran lagu edukasi matematika. Uji coba dilakukan sebanyak dua kali di SDN Keleyan 1 Socah, yaitu uji coba produk pada tanggal 8 Mei 2018 dan uji coba pemakaian pada tanggal 9 Mei 2018. Uji coba produk dilakukan setelah media pembelajaran lagu edukasi matematika selesai di validasi oleh para ahli dan menunjukkan hasil valid dan layak untuk digunakan.

Uji coba pemakaian dilakukan dalam skala yang lebih luas guna untuk menguji kemenarikan, keefektifan, dan kemenarikan media. Uji coba produk melibatkan 6 siswa kelas V SDN Keleyan 1 Socah yang merupakan 2 siswa dari kelas IV dengan kriteria kemampuan tinggi dan kurang, 2 siswa dari kelas $\mathrm{V}$ dengan kriteria kemampuan tinggi dan kurang, serta 2 siswa dari kelas VI dengan kriteria kemampuan tinggi dan kurang. Alasan pengembang memilih subjek uji coba dari kelas IV, V, dan VI dikarenakan siswa dari kelas tersebut memiliki kemampuan berfikir yang masih setara dan berada di lingkungan kelas tinggi. Uji coba pemakaian melibatkan 16 siswa secara keseluruhan yang tidak terlibat dalam uji coba produk.

Hal tersebut berdasar pada pendapat Rohman dan Amri (2016:149) bahwa pada uji coba pemakaian (kelas besar) dipilih sekitar 20 siswa dengan berbagai karakteristik (tingkat kepandaian, latar belakang, jenis kelamin, usia, 
kemajuan belajar, dan sebagainya) sesuai dengan karakteristik populasi sasaran.

Teknik analisis data dalam penelitian pengembangan ini menggunakan teknik analisis deskriptif dengan menggunakan rumus persentase dalam mengolah data yang diperoleh. Analisis kevalidan dalam pengembangan media lagu edukasi matematika diperoleh dari data hasil angket validasi pengembangan produk yang telah diberikan kepada para validator atau ahli yaitu ahli materi, ahli media dan ahli desain pembelajaran.

Analisis kemenarikan dalam pengembangan media lagu edukasi diperoleh dari data respon siswa terhadap produk melalui pengisian angket kemenarikan yang diberikan oleh pengembang pada tahap uji coba produk dan uji coba pemakaian. Analisis keefektifan diperoleh dari data hasil lembar observasi aktifitas guru, lembar observasi aktivitas siswa, dan hasil belajar yang diberikan oleh pengembang pada tahap uji coba produk dan pemakaian.

Analisis kepraktisan diperoleh dari data hasil respon guru terhadap media Lagu Edukasi Matematika yang diberikan oleh pengembang pada tahap uji coba pemakaian melalui pengisian angket respon guru.

\section{Hasil dan Pembahasan}

Lagu edukasi matematika adalah lagu yang lirik lagunya berisi tentang materi matematika khususnya bangun ruang kubus dan balok yang berjudul "Hai Kubus" dan "Bangunku Balok". Lagu ini bertempo sedang atau moderato sehingga mudah dinyanyikan oleh siswa dengan beformat MP3 sehingga dapat diputar di alat elektronik. Media ini dikemas dalam bentuk CD dan dilengkapi dengan buku panduan yang didalamnya berisi lirik lagu, notasi, dan materi bangun ruang kubus dan balok. Berikut adalah lirik lagu yang telah dikembangkan:

Tabel 1. Lirik Lagu Edukasi Matematika Hai Kubus

\section{"Hai Kubus"}

Kubus memiliki enam buah sisi Semuanya berbentuk persegi Enam buah sisi Hai, hai... kubus Jumlah rusuk kubus ada 12 Memiliki panjang yang sama Delapan titik sudut

Hai, hai... kubus

Reff :

Jika menghitung rusuk pangkat tiga Itu rumus volume bangun kubus Ayo kita belajar bersama sama

Tabel 2. Lirik Lagu Edukasi Matematika Bangunku Balok

"Bangunku Balok" 
Aku punya bangun ruang

Bangun balok itu namanya

Siapa tau rumus volumenya

Panjang kali lebar kali tinggi

Jumlah rusuknya dua belas

Titik sudutnya ada delapan

Jumlah sisinya ada enam

Tiga pasang sisi yang sama

Reff :

Ayo kawan kita belajar

Matematika itu menyenangkan

Jangan malas ayo belajar

Agar jadi anak yang pintar

Hasil dari media yang dikembangkan berdasarkan analisis kevalidan, kemenarikan, keefektifan, dan kepraktisan dijelaskan sebagai berikut: 1) persentase kevalidan produk media pembelajaran lagu edukasi matematika diperoleh dari hasil validasi para ahli yang meliputi ahli materi pembelajaran yaitu $98,67 \%$, ahli media pembelajaran yaitu $94,67 \%$ dan ahli desain pembelajaran 90,67\%, kemudian diinterpretasikan dalam tabel kriteria kevalidan media.

Berdasarkan hasil persentase validasi dari para ahli yang diperoleh dapat disimpulkan bahwa produk yang dikembangkan berada pada kriteria sangat valid; 2) persentase kemenarikan media pembelajaran lagu edukasi matematika diperoleh berdasarkan hasil respon siswa pada ujicoba produk dan pemakaian. Presentase angket hasil respon siswa pada ujicoba produk sebesar 96,67\% dan ujicoba pemakaian sebesar 97,50\%, kemudian diinterpretasikan dalam tabel kriteria kemenarikan media.
Produk yang dikembangkan berada pada kriteria sangat menarik; 3) presentase keefektifan media lagu edukasi matematika diperoleh berdasarkan hasil angket lembar observasi aktivitas guru dan siswa pada ujicoba produk dan pemakaian serta hasil belajar siswa pada ujicoba pemakaian. Pada ujicoba produk, presentase hasil observasi aktivitas guru sebesar $100 \%$, presentase hasil observasi aktivitas siswa sebesar 96,34\%. Pada ujicoba pemakaian, presentase hasil observasi aktivitas guru sebesar $100 \%$, presentase hasil observasi aktivitas siswa sebesar 96,25\% dengan hasil ketuntasan klasikal siswa 96,88\%.

Berdasarkan hasil presentase analisis keefektifan dapat disimpulkan bahwa produk yang dikembangkan berada pada kriteria sangat efektif dengan hasil ketuntasan klasikal yang tuntas; 4) presentase kepraktisan media pembelajaran lagu edukasi diperoleh berdasarkan hasil respon guru pada ujicoba pemakaian dengan presentase sebesar 100\%, kemudian diinterpretasikan dalam tabel kriteria kepraktisan media. Dari hasil tersebut, maka dapat disimpulkan bahwa produk yang dikembangkan berada pada kriteria sangat praktis dengan hasil, sehingga media dapat digunakan tanpa revisi.

Revisi produk bertujuan memperbaiki media pembelajaran yang dikembangkan untuk mengurangi kelemahan berdasarkan masukan dan saran para ahli serta hasil ujicoba produk dan pemakaian agar menjadi produk yang 
layak dan sesuai untuk siswa sebelum digunakan di sekolah dasar.

Ahli media memberikan nilai terhadap media yang dikembangkan dan memberikan saran yang digunakan oleh pengembang sebagai acuan untuk merevisi media pembelajaran yang dikembangkan. Masukan dan saran yang diberikan oleh ahli media yaitu tambahkan lirik lagu tanpa not angka, lirik dengan not angka hendaknya dipisah per bait dalam lagu, dan di kemasan kardus diberi gambar kubus dan balok.

Ahli desain pembelajaran memberikan nilai dan saran mengenai desain pembelajaran yang akan digunakan. Masukan dan saran yang diberikan akan menjadi acuan untuk merevisi produk yang dikembangkan. Adapun masukan dan saran yang diberikan oleh ahli desain yaitu: "Media sudah baik, RPP perlu diperbaiki pada bagian sumber belajar diperbaiki seperti penulisan daftar pustaka dan pada kisi-kisi soal evaluasi yaitu satu indikator minimal 2 soal".

Ahli materi memberikan nilai dan saran mengenai materi yang terdapat pada lagu edukasi matematika. Masukan dan saran yang diberikan oleh ahli materi yaitu "untuk konsep bangun ruang, kita perlukan pengenalan bangun datar terlebih dahulu". Media lagu edukasi mengulas konsep bangun ruang secara sederhana dan berlanjut pada materi inti yaitu sifat-sifat bangun ruang dan volumenya.

\section{Kesimpulan}

Berdasarkan data hasil analisis yang telah dijelaskan, maka produk yang dikembangkan ini sangat layak digunakan dalam proses pembelajaran untuk membantu guru dalam menjelaskan materi dan mempermudah siswa dalam belajar. Produk yang berupa media pembelajaran lagu edukasi ini layak digunakan pada mata pelajaran Matematika di kelas $\mathrm{V}$ dengan materi bangun ruang kubus dan balok, namun pengembangan menyadari bahwa media pembelajaran ini memiliki kekurangan dan kelebihan sehingga diperlukannya saran yang membangun untuk produk yang dikembangkan.

Saran pemanfaatan produk dari pengembangan media pembelajaran lagu edukasi matematika adalah guru dapat menggunakan lagu pembelajaran sebagai referensi dalam menyampaikan materi Matematika di kelas $\mathrm{V}$ yaitu materi bangun ruang dan kubus serta guru dapat mengajak siswa belajar sambil bernyanyi, lagu edukasi akan lebih bermanfaat jika digunakan dengan berbantuan buku panduan penggunaan media dan lebih bermakna jika melibatkan siswa dalam proses pembelajaran serta media lagu edukasi matematika akan lebih menyenangkan dan bermanfaat jika pada penyampaian lagu dan materi menggunakan metode pembelajan yang menyenangkan dan kreatif sehingga siswa tidak mudah bosan dalam mengikuti proses pembelajaran.

Saran pengembangan produk dari pengembangan media pembelajaran lagu edukasi matematika adalah media lagu edukasi 
matematika materi bangun ruang kubus dan balok untuk kelas $\mathrm{V}$ masih diujicobakan di satu sekolah, agar media lagu edukasi dapat digunakan pada sekolah lain maka produk ini dapat diujicobakan pada sekolah dasar yang lain.

\footnotetext{
Pada penelitian selanjutnya, diharapkan dapat mengembangkan lagu edukasi dengan mata pelajaran dan materi yang berbeda pada tingkatan kelas yang berbeda pula serta sebelum disebarluaskan sebaiknya produk diteliti terlebih dahulu dan disesuaikan dengan kurikulum yang digunakan di sekolah dan karakteristik siswa. Selanjutnya, sebelum menyebarluaskan lagu edukasi matematika di khalayak umum, sebaiknya memperoleh hak cipta terlebih dahulu.
}

\section{Pustaka}

Hamid, Sholeh. 2014. Metode Edutainment. Yogyakarta: DIVA Press

Musfiqon. 2012. Pengembangan Media dan Sumber Pembelajaran. Jakarta: PT. Prestasi Pustakarya.

Rasyid, Fathur. 2010. Cerdaskan Anakmu Dengan Musik. Yogyakarta: DIVA Press.

Rohman, Muhammad dan Sofan Amri. 2016. Strategi dan Desain Pengembangan Sistem Pembelajaran. Jakarta: Prestasi Pustakarya

Sugiyono. 2014. Metodologi Penelitian. Bandung: Alfabeta. 